\title{
Eu e a fita verde no cabelo - conceitos de Freud no conto de Guimarães Rosa
}

Heurisgleides Sousa Teixeira ${ }^{1}$

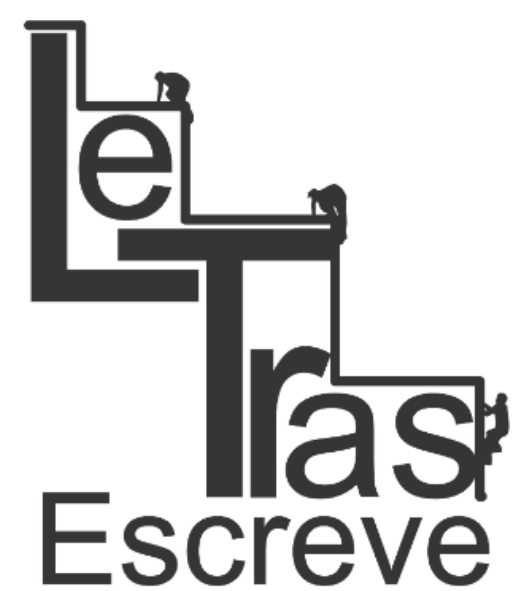

(ISSN 2238-8060)
Resumo: O objetivo deste artigo é propor uma análise do conto "Fita verde no cabelo", de João Guimaraes Rosa, a partir da teoria da psicanálise, de Freud, sobretudo com seu famoso ensaio Além do princípio de prazer, de 1929. O conto recria, num universo inóspito e pouco propício à fábula, a história de chapeuzinho vermelho, vivida pela personagem nomeada pelo narrador como "Fita verde". Toda a simbologia do conto clássico é revivida e transformada no enredo pela personagem, numa elaboração poética que, ao tempo em que rememora, modifica o passado e, numa via de mão dupla, modifica também o presente. Daí o subtítulo do conto, "nova velha história". No plano teórico-metodológico, trata-se de estabelecer um diálogo no qual, a partir da teoria da psicanálise, se gere uma chave de leitura para o conto e, simultaneamente, o conto seja uma metáfora da teoria.

Palavras-chave: Memória; Literatura; Psicanálise; Guimarães Rosa.

Resumen: El objetivo de este artículo es proponer un análisis del cuento "Fita verde no cabelo", de João Guimarães Rosa, a partir de la teoría de la psicoanálisis, de Freud, sobretodo en su famoso ensayo Além do princípio de prazer, de 1929. El cuento recría, en un universo inhóspito y poco afecto a la fábula, la historia de chapeuzinho vermelho, vivida por el personaje nombrado por el narrador cómo "Fita verde". Toda la simbología del cuento clásico es revivida y cambiada en el enredo por el personaje, en una elaboración poética que, al mismo tiempo en que acuerda, modifica el pasado y, en una doble vía, modifica también el presente. Esta es el motivo del subtítulo del cuento, "nova velha história". En el plan plano teórico-metodológico, trata-se de establecer un diálogo en el cual, a partir de la teoría de la psicoanálisis, se encuentre una clave de lectura para el cuento y, al mismo tiempo, el cuento sea una metáfora de la teoría.

Palabras-clave: Memoria; Literatura; Psicoanálisis; Guimarães Rosa.

\section{Introdução}

Para Marcos e Eduardo

O objetivo deste trabalho é discutir alguns conceitos fundamentais em Freud, tais como princípio de prazer e princípio de

\footnotetext{
${ }^{1}$ Professora de literatura da Universidade do Estado da Bahia - UNEB e doutoranda do programa de Teoria e História Literária da Universidade Estadual de Campinas - UNICAMP.
}

https://periodicos.unifap.br/index.php/letras

Macapá, v. 6, n. I, Io semestre, 2016. 
realidade, pulsão de vida e pulsão de morte, além de algumas considerações sobre trauma, compulsão à repetição e angústia, a partir do ensaio Além do princípio do prazer, publicado em 1920. Argumento, com essa discussão, que a angústia constrói uma espécie de memória antecipada para o choque, ou para o que poderíamos chamar de tragédia, com o que pretendo propor a imagem de uma memória do futuro. Para tanto, utilizarei alguns exemplos retirados do conto "Fita verde no cabelo: nova velha história”, de João Guimarães Rosa, por considerá-lo um texto que ajuda a esclarecer as questões ora discutidas.

\section{Princípio de prazer e princípio de realidade - o caminho longo e o caminho curto}

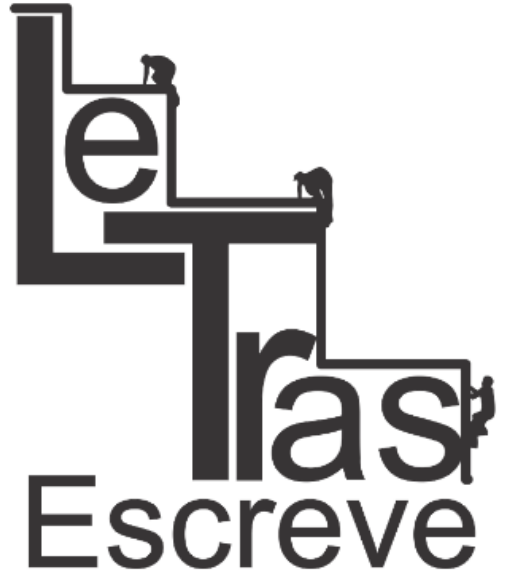

(ISSN 2238-8060)

Começo pelo modo como se estabelece para Freud (2010, p. 164) a relação entre princípio de prazer e princípio de realidade ${ }^{2}$. Freud utiliza um "fator econômico" pautado na "quantidade de excitação", entendendo que um desprazer é algo como um desequilíbrio da excitação, "um desconforto", que gera um aumento da tensão. A resolução dessa tensão diminui a excitação e, em estado de repouso, o princípio de prazer é restabelecido. Isto porque, de acordo com suas observações, "o aparelho psíquico se empenha em conservar a quantidade de excitação nele existente o mais baixa possível, ou ao menos constante".

É curioso, no entanto, que apesar desse desejo pela estabilidade, nem sempre o resultado final dessa equação "corresponde ao prazer". Fazer somente o que quer não garante a sobrevivência de ninguém. Portanto, desde já, essa relação entre prazer-realidade está intimamente ligada às pulsões de vida e de morte também discutidas no mesmo texto. A fim de sobreviver, ou

\footnotetext{
${ }^{2}$ Sabemos que Freud revisitou muitas vezes os conceitos que apresenta em sua teoria. Como disse na introdução, as ideias aqui apresentadas dizem respeito ao Além do princípio do prazer, embora saibamos que eles foram posteriormente discutidos.
}

https://periodicos.unifap.br/index.php/letras Macapá, v. 6, n. I, Io semestre, 2016. 


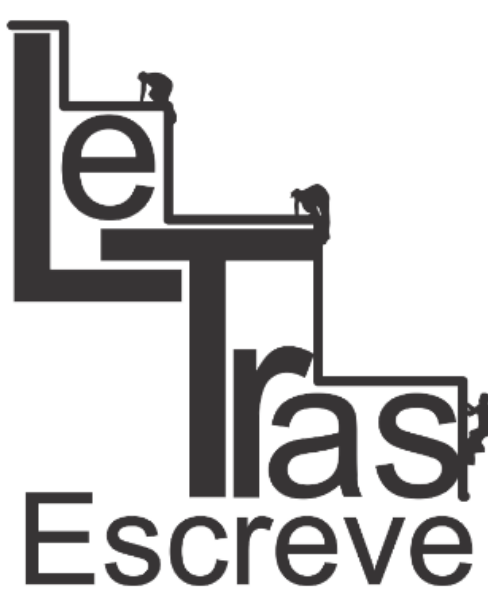

(ISSN 2238-8060) como dirá Freud $\left(2010\right.$, p. 165) ${ }^{3}$ mais adiante, a fim de "morrer do seu próprio modo", o sujeito adia a "a satisfação" em prol da prevalência do princípio de realidade. Ele aceita "o desprazer num longo rodeio para chegar ao prazer".

Essa repressão dos instintos, segundo Freud, não é a única causa de desprazer à qual o sujeito se impõe. À medida que amadurece, o sujeito vive conflitos internos, pelo fato de que muitos dos seus instintos passam a ser inaceitáveis para ele em determinadas "fases do desenvolvimento" (p. 166). Resumidamente, podemos dizer que aí ocorre um paradoxo, já que um prazer pode ser "sentido como desprazer pelo Eu" quando sua meta era reprimir uma satisfação, mas mesmo assim ela vem à tona. Segundo Freud, "todo desprazer neurótico é desse tipo, é prazer que não pode ser sentido como tal" (p. 167).

Se Freud propõe uma economia da relação entre os dois princípios, quero propor aqui uma geografia, marcada pela escolha do caminho feita por Fita Verde, uma Chapeuzinho Vermelho reinventada por Guimarães Rosa. Assim como a menina do capuz vermelho, a personagem de Rosa sai de casa, por ordem da mãe, para ir até a casa de sua avó em uma "outra e quase igualzinha aldeia". Em suas mãos, um pote de doce e um cesto vazio, "que para buscar framboesa". Quero, assim, estabelecer com esse conto uma analogia das questões discutidas por Freud em seu Além do princípio do prazer.

O diálogo da "nova velha história" com o conto clássico acontece, muitas vezes, pela ausência de elementos. Por exemplo, ao contrário de Chapeuzinho, na história de Fita Verde, não havia lobo "nenhum, desconhecido nem peludo" no bosque. Essa ausência, no entanto, é suprida pela presença textual, pois a palavra lobo o presentifica no exato momento em que ele faria seu papel

\footnotetext{
3 Todos os trechos citados do autor estão na edição das suas Obras Completas, publicadas pela Companhia das Letras, no vol. 14. Assim, para uma economia do texto, passo a indicar ao final de cada passagem a página onde se localiza cada citação.
} 


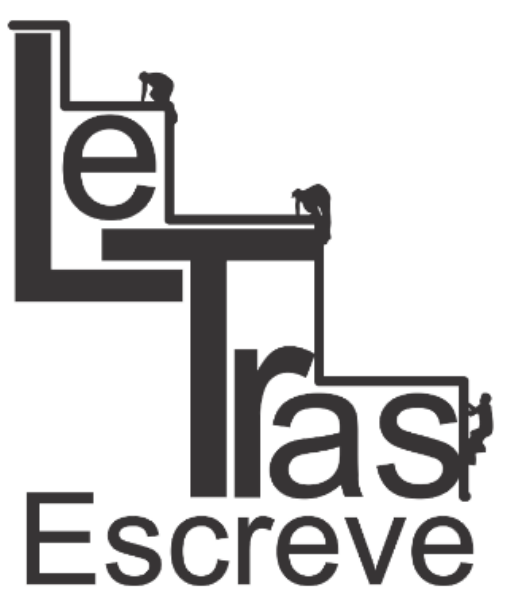

(ISSN 2238-8060)

fundamental de indicar o caminho para a menina. Como não aparece, presente na ausência, ela mesma é que tem que escolher a sua trajetória, sua travessia. Porém, ao invés de ir pelo mais óbvio e reto, o "caminho encurtoso", ela escolhe o outro, "Iongo e louco", rememorando o conto clássico.

É na materialização desse caminho que a menina percorre até a casa de sua avó que quero propor a representação do conflito entre o princípio de prazer e o princípio de realidade. Sabe-se, no conto, que a "avó a amava" e mesmo assim Fita Verde adia o momento de chegada, demorando-se pela estrada afora, envolvida por uma fantasia por ela mesma criada, mas que a realidade, representada pela fala do narrador, insiste em quebrar. Em sua aldeia, lugar como outro qualquer, todos seguiam a vida como tinha que ser, o que é representado na fala do narrador por um discurso tautológico: "velhos e velhas que velhavam, homens e mulheres que esperavam, meninos e meninas que nasciam e cresciam".

Podemos descrever nessa geografia o caminho "encurtoso" como o princípio de realidade, caminho sem distrações e reto, que levaria a menina rapidamente à casa da sua avó para cumprir a tarefa dada pela mãe. Ao contrário, no entanto, ela sai de casa "com o cesto vazio, que para catar framboesas", o que já indica um adiamento com o inevitável compromisso". No caminho "longo e louco", regido obviamente pelo princípio de prazer, a menina se admira com o fato de "ver as avelãs no chão não voarem" e porque as borboletas nunca podem ser apanhadas como "um buquê". O leitor poderá dizer: ora, mas avelãs não voam mesmo e borboletas não são mesmo flores para formar um buquê; e é esse óbvio que a menina, única de sua aldeia que não tem "juízo suficientemente" se recusa a ver, resistindo o quanto pode, demorando-se no caminho exatamente para não ter que encarar a secura do que no conto é o seu mundo real. No entanto, esse "desprazer", ou esse "aumento da

\footnotetext{
${ }^{4}$ Adio também o compromisso e a explicação do porque ele é inevitável.
} 
tensão", ou esse "princípio de realidade" falará mais alto quando a menina enfim chegar à casa da sua avó.

Princípio de prazer e princípio de realidade. Pulsão de vida, pulsão de morte. Esses pares opositivos suscitam como que uma sístole e uma diástole, ou um movimento pendular, um constante ir e vir. Reproduzindo-os, interrompo aqui a exposição do conto e volto a Freud, para mostrar como ele discute a questão das pulsões do seu Além do princípio do prazer.

\section{Pulsão de vida e pulsão de morte -o caminho longo e o caminho longo de novo}

Embora o princípio do prazer exerça uma grande influência

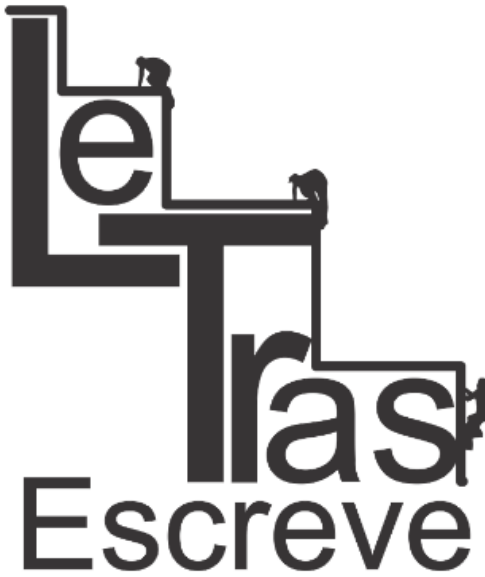

(ISSN 2238-8060) sobre os processos psíquicos, ele não domina tais processos e o "resultado final nem sempre corresponde à tendência ao prazer" (FREUD, 2010, p. 165). É, aliás, fundamental para o desenvolvimento que os instintos sejam reprimidos e, assim, que o estado de "baixa tensão" seja constantemente desfeito.

Para argumentar como funciona esse impulso para o desenvolvimento apesar do princípio de prazer, Freud toma como exemplo um organismo simples, unicelular, como um protozoário, para demonstrar suas reações a estímulos e, depois, demonstrar como isso se dá com o ser humano. A membrana que delimita esse ser primitivo é não só responsável por receber os estímulos do exterior, mas também por 'filtrar' tais estímulos. Com isso, o organismo não recebe os impactos exatamente como eles chegam à membrana.

Ocorre, porém, que para chegar a esse nível de proteção, é possível que o ser primitivo tenha morrido muitas vezes no processo de evolução. Freud supõe, então, que uma primeira forma de vida tenha, durante muito tempo, sofrido estímulos externos e, sem proteção, tenha imediatamente morrido. Para escapar dessa morte repentina, em algum momento, ela reagiu de modo diferente e, 
assim, se desviou da morte. A essa reação primeira, a reação que nos leva a escapar da morte, Freud chama pulsão de vida.

Assim, por longo tempo a substância viva pode ter sido repetidamente criada, sempre morrendo com facilidade, até que decisivas influências externas mudaram de forma tal que obrigaram a substância ainda sobrevivente a desviar-se cada vez mais do curso da vida original e fazer rodeios cada vez mais complicados até alcançar a meta de morte (p. 205).

Longe de nos colocar a nós humanos em uma escala evolutiva que, por um impulso interior ou por uma busca por perfeição, nos tornou mais complexos que um ser unicelular, Freud diz não haver necessidade de uma "explicação diferente". Apenas "forças externas" foram responsáveis por impor uma mudança no curso das nossas vidas e, consequentemente, por aumentar a complexidade do nosso organismo, de modo que pudéssemos o mais que possível fugir da morte. Ainda de acordo com ele, a embriologia mostra que a parte do nosso "córtex cerebral" responsável pela recepção desses estímulos "é ainda um derivado da superfície primitiva e poderia ter herdado características essenciais desta" (p. 187). E mais adiante: "Nos organismos altamente desenvolvidos, a camada cortical receptora da ex-vesícula retirou-se há muito para as profundezas do interior do corpo, mas porções dela ficaram na superfície, imediatamente abaixo da proteção geral contra os estímulos" (p.189). Tais porções são os órgãos dos sentidos, os quais funcionam como "antenas", para perceber e se afastar do excesso de estímulo.

Já vimos, no início, que o excesso de estímulo produz um desconforto para o organismo e ele, então, associa o prazer à estabilidade. Por isso, Freud diz que os seres, de um modo geral, são extremamente conservadores. Exemplos na natureza abundam nesse sentido: as aves migram todos os anos e as tartarugas também, para se reproduzirem sempre nos mesmos locais que eram provavelmente o habitat dos seus ancestrais. Para Freud, essas são

https://periodicos.unifap.br/index.php/letras Macapá, v. 6, n. I, Io semestre, 2016. 


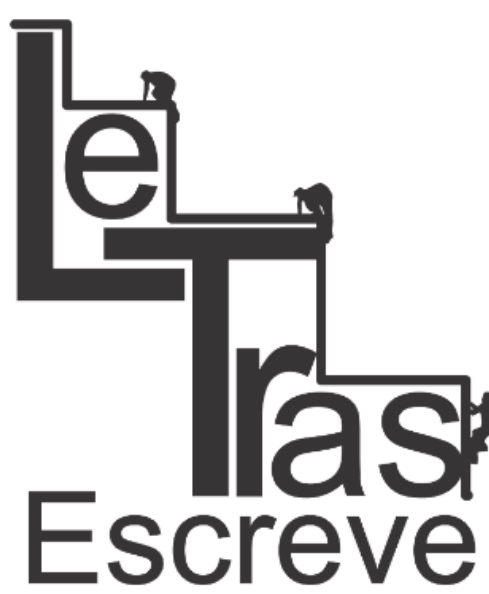

(ISSN 2238-8060) "as provas mais formidáveis de uma orgânica compulsão a repetir" (p. 202).

Essa tendência à repetição leva Freud a levantar a "hipótese de que todos os instintos querem restabelecer algo anterior" (p. 203). Ora, se tomarmos o breve percurso da vida do ser primitivo, veremos que ele partiu de um estado inorgânico e, por muito tempo, sua reação aos estímulos externos foi voltar a esse estado. À medida que foram se tornando mais complexos, os organismos foram alongando o percurso até retornar ao estado inorgânico novamente. A esse desejo de retorno, Freud denomina pulsão de morte. "Se é lícito aceitarmos, como experiência que não tem exceção, que todo ser vivo morre por razões internas, retorna ao estado inorgânico, então só podemos dizer que o objetivo da vida é a morte" (p. 204).

Voltemos a Chapeuzinho, ou melhor, a Fita Verde e sua geografia. Vimos que a personagem, na ausência do lobo, decide por si mesma qual caminho trilhar. Considerando, mais uma vez, a geografia, isto é, o tempo-espaço que a menina levaria tomando um ou outro caminho, atribuo ao caminho longo a pulsão de vida, pois é esta que impele o sujeito para diante, no curso do seu desenvolvimento, com seu instinto de auto conservação, evitando a morte (porque é com ela que a menina - e também Chapeuzinho vai se deparar no fim da travessia).

Seria então tentador dizer que o caminho curto, reto, estaria mais vinculado à pulsão de morte. Mas não funciona assim. A pulsão de morte, representada pelo desejo oculto ou inconsciente de retorno ao estado inorgânico, pela compulsão à repetição, também está relacionada ao caminho longo. Como resolver essa aparente incoerência ou lacuna que parece resistir à minha proposta de tornar a 'geografia' do conto uma analogia da teoria freudiana?

Se tentarmos estabelecer um diagrama, veremos que essa aparente contradição encontra-se muito bem fundamentada nos argumentos do próprio Freud, de modo que, no fim, ambas as

https://periodicos.unifap.br/index.php/letras Macapá, v. 6, n. I, Io semestre, 2016. 
pulsões apontam para o mesmo lugar: o estado de ausência de tensões, estado inorgânico, estado de morte. Ele mesmo admite que parece contraditório dizer que "os instintos conservadores" estão como que a serviço da "realização da morte". Mas resolve o problema da seguinte forma:

O que daí resta é que o organismo pretende morrer apenas a seu modo; tais guardiães da vida também foram, originalmente, guarda-costas da morte. Surge então o paradoxo de que o organismo vivo se rebela fortemente contra influências (perigos) que poderiam ajudá-lo a alcançar sua meta de vida por um caminho curto (mediante curto-circuito, digamos), mas essa conduta caracteriza justamente os esforços apenas instintuais, em oposição aos inteligentes (p. 206, grifo nosso).

\section{Angústia como "memória" do futuro}

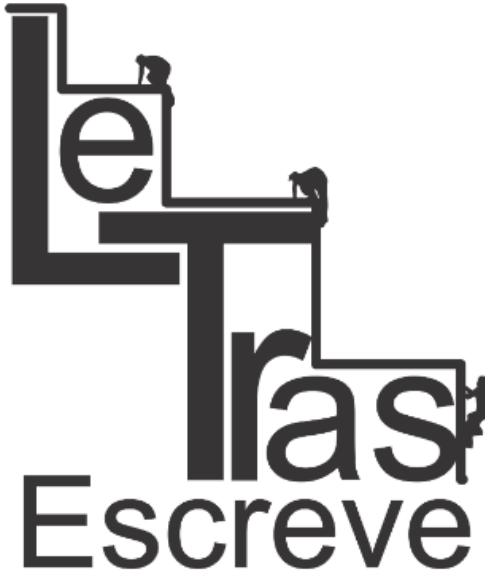

(ISSN 2238-8060)

No mesmo ensaio que aqui apresento, Freud pontua a diferença entre terror, medo e angústia. $O$ medo, diz, está diretamente relacionado a um objeto. Mas a angústia e o terror têm uma relação mais evidente: o terror é "o estado em que ficamos ao correr um perigo, sem estarmos para ele preparados, enfatiza o fator surpresa", ao passo que a angústia é uma "expectativa do perigo e preparação para ele, ainda que seja desconhecido" e, por isso, funciona como uma proteção (p. 169).

Para mostrar a função da angústia como proteção, apresento a leitura de Cathy Caruth (1996) sobre uma imagem literária que Freud apresenta em Além do princípio do prazer e que exemplifica um momento traumático. Trata-se da história escrita por Tasso, Gerusalém libertada, que aqui apresento na leitura de Caruth. No mito, Tancredo mata duas vezes a sua amada Clorinda. Isso se dá porque, no primeiro momento, estando ela disfarçada em uma roupa de guerreiro, o casal duela e Tancredo a fere de morte. No segundo, passando por uma floresta encantada com seus companheiros, Tancredo finca sua faca em uma árvore; da "ferida" sai sangue, mas ainda mais grave, sai a voz de Clorinda dizendo a ele que era a 


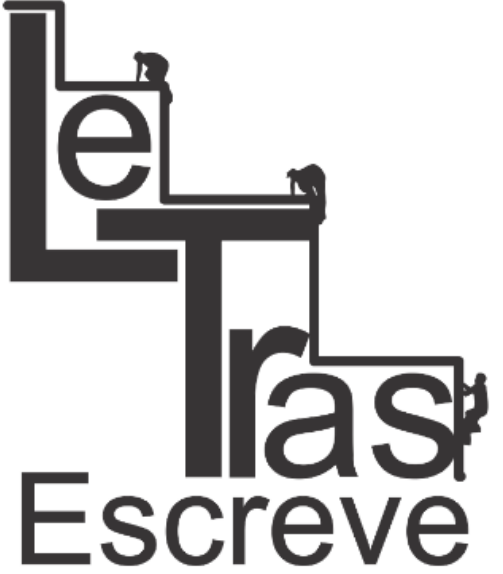

(ISSN 2238-8060)

segunda vez que a matava. A história de Tancredo e Clorinda é uma metáfora do modo como o trauma acontece, porque é só no segundo momento que ele se dá conta do que aconteceu e se depara com o terror ${ }^{5}$.

No meio médico, o termo trauma é utilizado no exato sentido de uma ferida aberta no corpo. Nesse sentido, a ferida, que é uma metáfora na árvore (porque representa a ferida em Clorinda), provoca também uma ferida em Tancredo; a esta última Freud denomina trauma, aquela ferida psíquica provocada pelo choque com o inesperado. Como a primeira inflição de Tancredo que fere de morte Clorinda é uma experiência tão precoce, tão inesperada, para ser totalmente entendida, ela não pode ser avaliável conscientemente até que ela se imponha novamente, repetidamente, em pesadelos e ações do sobrevivente (cf. Caruth, 1996, p. 04). Assim, explica Caruth, o trauma não está no primeiro nem no segundo momento, mas na relação entre os dois.

Em seu ensaio, Freud afirma que pessoas que sofreram traumas de guerra têm sonhos repetitivos e acordam aterrorizadas. Como disse no item anterior, possuímos uma estrutura mental que filtra os estímulos externos e, por isso, eles chegam à consciência de forma menos intensa. No momento do choque, porém, essa proteção falha e os estímulos como que a atravessam, indo direto para os recônditos do inconsciente. O contrário se dá quando algo internamente nos protege do horror, que é essa expectativa de perigo denominada de angústia. O sujeito traumatizado, que vivenciou o choque, reproduz constantemente a situação; ainda que sua consciência recalque o ocorrido, em sonhos ele o reproduz, como se fosse possível, desse modo, construir a posteriori a proteção contra o evento traumático.

\footnotetext{
${ }^{5}$ Kaplan (2005) mostra, em seu livro sobre trauma, como ela mesma vivenciou a experiência do trauma quando, ao visualizar o atentado às Torres Gêmeas nos EUA, suas reações, medos, angústias se misturavam com recordações da infância vivida em plena guerra mundial, na Inglaterra.
}

https://periodicos.unifap.br/index.php/letras

Macapá, v. 6, n. I, Io semestre, 2016. 


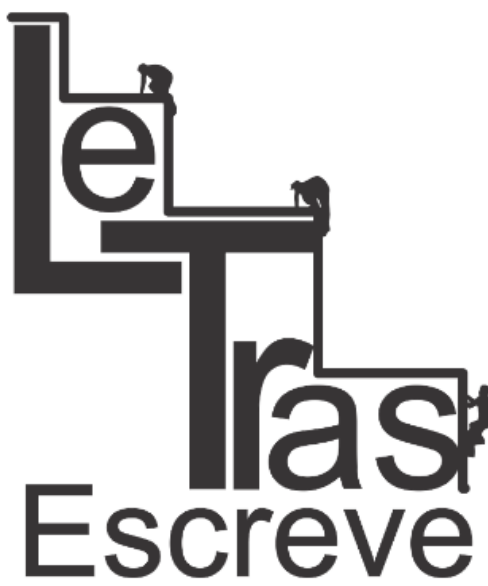

(ISSN 2238-8060)

De acordo com Loffredo (2012), a teoria de Freud sobre a angústia passou por pelo menos três momentos ${ }^{6}$. Outros autores, como Lourenço; Viana; de Paula (2011) dividem a teoria em duas etapas. De um ou outro modo, interessa-nos aqui o que vem a ser a última das suas formulações, segundo os comentadores, porque é a que consta em Além do princípio do prazer.

Já vimos que o aparelho psíquico possui um mecanismo de defesa contra os estímulos externos, o que serve também para que haja sempre um constante equilíbrio entre as pulsões. O trauma consiste exatamente na ruptura desse mecanismo e, portanto, na "invasão excessiva de estímulos" (LOURENÇO et all, 2011, p. 72), de modo que o aparelho não consegue transformar toda essa carga de estímulo em representação.

Por causa desse rompimento, desencadeia-se no indivíduo traumatizado a compulsão à repetição ${ }^{7}$ cuja função, nesse caso, é desenvolver, a posteriori, a proteção que falhou com o susto ou o choque traumático. Daí a frequência de sonhos ou crises de angústia, como uma tentativa do inconsciente de criar as condições para que o excesso de estímulos seja enfim simbolizado. Assim, "a compulsão à repetição teria a função de desenvolver retrospectivamente a angústia, a qual não teria se apresentado no

6 "Podemos verificar três tempos matrizes na produção teórica de Freud sobre a angústia: as concepções de 1895 , nas quais a angústia é concebida como uma descarga somática, efetuada sem a participação do psiquismo, no âmbito das neuroses de angústia (Freud, 1895b/1989; 1895c/1989); o segundo momento, em 1909, quando a histeria de angústia é classificada como um processo patológico independente, sendo a angústia entendida como um dos produtos possíveis da repressão, por meio do processo de transformação da libido (Freud, 1909a/1990); e a "virada" de 1926, em "Inibição, sintoma e angústia" (Freud, 1926/1990), que pretende ser uma reformulação da teoria anterior, com a utilização dos ingredientes teóricos fornecidos pela perspectiva do segundo dualismo pulsional e da segunda tópica" (LOFFREDO, 2012, p. 106)

${ }^{7} \mathrm{~A}$ compulsão à repetição não se refere somente a casos dessa natureza. Indivíduos ditos não neuróticos também realizam essa operação e a entendem como se fosse um golpe do destino. Mas Freud afirma que "esse destino é preparado por elas mesmas e determinado por influências da primeira infância" (p. 181) A essa repetição, Freud denomina "eterno retorno do mesmo" (p. 182).

https://periodicos.unifap.br/index.php/letras

Macapá, v. 6, n. I, Io semestre, 2016. 


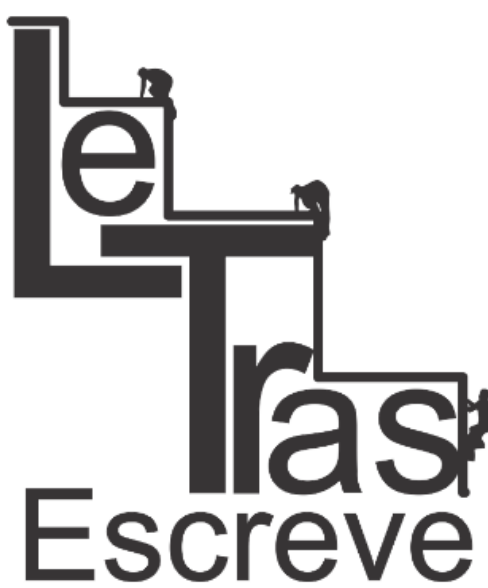

(ISSN 2238-8060) momento do trauma" (LOURENÇO et all, 2011, p. 72). É a partir dessa tentativa de criar uma expectativa a posteriori que quero propor a imagem da angústia como memória do futuro, quando ela ocorre antes do choque.

As teorias da memória mostram, desde a antiguidade, que a faculdade da memória está vinculada à imaginação. Imaginação: capacidade cognitiva de criar imagens. "A parte da alma que cria imagens é considerada, em Aristóteles, como um a priori para o processo intelectual mais 'elevado'” (SELIGMAN-SILVA, 2006 p. 31), porque o pensamento consiste também em ser capaz de criar uma "imagem mental". Independentemente da topografia cerebral que Aristóteles propõe, é válido pensar que a imaginação, que está relacionada à memória, também é capaz de "criar imagens independentes, como ocorre quando sonhamos", quando fazemos planos para o futuro ou quando inventamos uma história. É assim, aproximando o conceito de angústia de Freud com o conceito de imaginação acima apresentado que proponho a angústia como memória do futuro, no sentido de uma projeção.

Volto ao caminho de Fita Verde uma última vez. Essa angústia pode ser representada, mais uma vez, pelo caminho escolhido pela menina, porque a opção de adiar sua chegada pode aqui representar a preparação para o choque que ela sofrerá. Repetindo o caminho de Chapeuzinho Vermelho, então ela imagina o terror de encontrar, na casa da avó, o lobo, representação nas histórias infantis dos medos da infância8 ${ }^{8}$.

Mas, por mais que adie, em um momento, a menina chega à casa da avó. Chega cansada, com características bastante realistas para um conto de fadas - "suada e com enorme fome de almoço", porque o princípio de realidade aí grita em todos os seus (órgãos dos) sentidos. Assim, tentando repetir mais uma vez Chapeuzinho, a menina reformula as perguntas e as adapta para a avó que, dessa

${ }^{8} \mathrm{~A}$ leitura dos contos clássicos pelo foco da psicanálise não poderia deixar de ter uma base em B. BETTELHEIM, em seu livro $A$ psicanálise dos contos de fada.

https://periodicos.unifap.br/index.php/letras

Macapá, v. 6, n. I, Io semestre, 2016. 
vez, ocupa o lugar do lobo, superpondo e modificando imagens do conto clássico:

- Vovozinha, que braços tão magros os seus, e que mãos tão trementes!

- É porque não vou poder nunca mais te abraçar, minha neta...

- a avó murmurou.

- Vovozinha, mas que lábios tão arrocheados!

- É porque não vou nunca mais poder te beijar, minha neta... a avó suspirou.

- Vovozinha, e que olhos tão fundos e parados, nesse rosto encovado e pálido?

- É porque já não te estou vendo, nunca mais, minha netinha... - avó ainda gemeu.

Importa destacar que, ao chegar à casa da avó, a menina percebe que perdera a grande fita verde "inventada" que trazia no cabelo. Como poemas, nas narrativas de Rosa as palavras não são

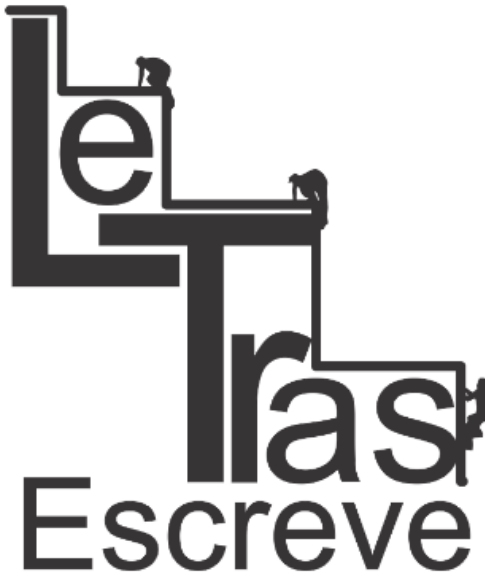

(ISSN 2238-8060) nunca gratuitas. Pensando nessa não gratuidade, Menezes (2010, p. 274) propõe uma leitura para a cor da fita não apenas no que diz respeito ao verde estar relacionado ao início da vida, na natureza aos "Estados 'não maduros". Muito bem aplicado ao conto, o verde anuncia um novo ciclo: "É assim que na primavera as folhas que amarelaram no outono e caíram no inverno, rebrotam - verdes. Daí: verdejar, reverdecer. E por uma convenção universal, verde é a cor da esperança".

Ao presenciar a morte da avó, a ela sofre a realidade do seu mundo. O medo que tem, fantasiado no medo do lobo, é o medo da morte real que agora tem que enfrentar -morte da avó, mas também sua própria morte, porque representa o fim daquilo que ela mesma é e, "como se fosse ter juízo pela primeira vez", a menina grita:

- Vovozinha, eu tenho medo do lobo! Mas a avó não estava mais lá, sendo que demasiado ausente, a não ser pelo frio, triste e tão repentino corpo. 


\section{Considerações finais: viver é muito perigoso}

Não é à toa que a palavra "travessia" é tantas vezes atribuída a Guimarães Rosa em sua obra inteira e não apenas no Grande Sertão em que Riobaldo a utiliza. Costumo afirmar que todos os contos de Rosa e suas novelas são veredas do grande sertão, que é do tamanho do mundo: "Assaz o senhor sabe: a gente quer passar um rio a nado, e passa; mas vai dar na outra banda é num ponto muito mais embaixo, bem diverso do em que primeiro se pensou. Viver nem não é muito perigoso?" (ROSA, 2006, p. 26).

Assim como Riobaldo, a menina faz sua travessia, imaginando que adiante vai encontrar o lobo e repetir a velha história. Mas do outro lado do caminho, numa sequência de inversões em relação à história de Chapeuzinho, as surpresas de Fita Verde, quando a situação real torna-se símbolo do simbólico: a avó faz o papel do lobo no clássico diálogo, mas não devora a menina; não é forte (braços magros, mãos trementes, lábios arrocheados) e no entanto causa medo, no momento mais tenso da história, momento da sua própria morte.

A menina então se depara com a realidade, cumpre sua missão, "a qual ela não sabia qual", parafraseando outro narrador roseano9: repetindo como que os passos de um ancestral imaginado, abre mão do princípio de prazer, representado na sua "grande fita verde no cabelo atada", em função do princípio de realidade e enfrenta com horror a morte da avó. Nesse ritual de passagem, a morte deixa de ser uma metáfora e passa a representar-se a si mesma no "frio, triste e tão repentino corpo da avó". Como se fosse na vida real.

A memória, nesse conto, fala por todos os lados. As atitudes da menina rememoram a "velha história". O caminho que ela faz é o ritual de passagem pelo qual todos têm que passar, da fantasia da infância para o enfrentamento da realidade sem máscaras e o

9 Trata-se do narrador do conto "Pirlimpsiquice", em Primeiras estórias. 


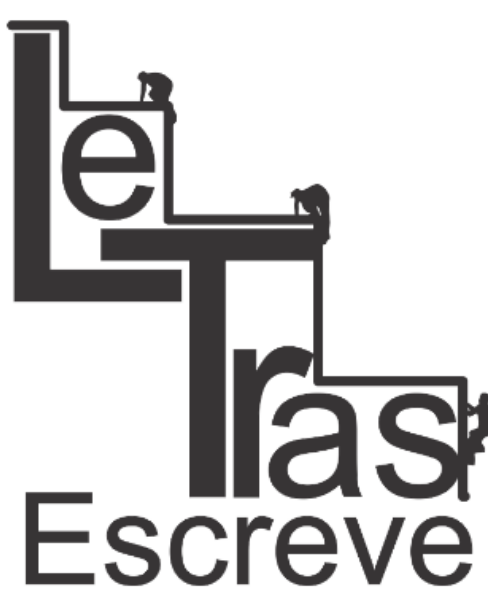

(ISSN 2238-8060)

domínio do seu próprio universo. O leitor, lendo pela primeira vez, pensa que apenas relê, porque também ele rememora o conto clássico. E o final, que em Rosa surpreende, surpreende apenas pelo choque que ele mesmo - leitor - sofre pela inesperada crueza com que a metáfora é exposta.

A memória aqui, que prevê o futuro, é ao mesmo tempo do passado, porque re-memora o já conhecido, o que se parece muito com a definição freudiana de compulsão por repetição - do autor, da personagem, do leitor. O movimento da pulsão de vida não evitou o encontro com a morte - pelo autor, pelo leitor, pela personagem. A ida à casa da avó (retorno ao clássico, de novo compulsão por repetição) sugere um retorno ao seu próprio lar, quando o caminho que percorreu será visto certamente com outros olhos pela menina, imaginado pelo leitor, quiçá já visto pelo autor. Porque essa morte real representada no conto é, de novo, um símbolo, pois que representa a morte da "por enquanto" meninazinha do início do conto, que agora renasce para o mundo adulto.

Mas, com Freud, sabemos que essa meninazinha nunca morre totalmente dentro de nós.

\section{Epílogo}

Desde setembro do ano de 1998, meu pai adoeceu gravemente. Antes disso, ele já havia tido problemas com hipertensão, mas sua doença se agravou na mesma semana em que minha filha nascia. Isso foi há dezesseis anos, quando ele sofreu um derrame. Desde então, não sei quantas crises cardíacas meu pai sofreu. Uma, que foi diagnosticada como infarto do miocárdio não ceifou sua vida e ele ainda viveu outros tantos internamentos e o acréscimo de um sem número de medicações e mais uma série de problemas consequentes daquilo que toda vez tinha um novo nome e terminou como insuficiência cardíaca, em abril de 2011. Em quase todas elas estive presente ao tratamento,

https://periodicos.unifap.br/index.php/letras Macapá, v. 6, n. I, Io semestre, 2016. 


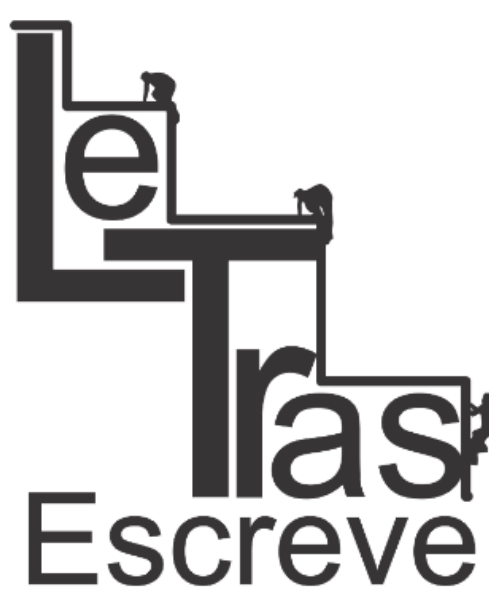

(ISSN 2238-8060)

exceto na primeira. Às vezes, me internava junto com ele, passava dias no hospital. Na última, fiz algo diferente. Daquilo que já fazia quase parte de uma rotina ou um ritual, transformei em um relato e escrevi um email aos meus amigos mais próximos. Disse que meu pai passava por mais uma crise; disse que ele era como uma criança teimosa; disse que eu estava junto com ele no hospital, mas que, como sempre, dali uns dias, ele voltava para casa como se nada tivesse acontecido... poucos dias depois, escrevi um email para os mesmos amigos informando que ele não havia resistido.

Um desses amigos me chamou a atenção para o fato de que nunca, antes daquela que foi a última internação do meu pai, eu havia feito aquilo, isto é, nunca eu havia informado a todos que ele estava no hospital. Por outras circunstâncias, as pessoas ficavam sabendo. Mas por que dessa última vez eu fiz isso? Na ocasião, eu não soube responder. Depois de ter lido alguns estudos de Freud e mais outros trabalhos sobre a teoria do trauma, posso ensaiar uma explicação. Fui a Chapeuzinho Vermelho, fui a Fita Verde. Ainda sou. Fiz meu caminho longo e louco. Com muita angústia me preparei para o final.

\section{Referências bibliográficas}

BETTELHEIM, B. A psicanálise dos contos de fada. Rio de Janeiro: Paz e Terra, 1980.

CARUTH, C. Unclaimed experience. Trauma, narrative and history. Baltimore, Londres: Johns Hopkins University Press, 1996.

FREUD, S. Além do princípio do prazer. In: Obras completas. vol. 14. São Paulo: Cia das Letras, 2010.

KAPLAN, E. Ann, Trauma Cuture. The Politics of Terror and Loss in Media and Literature, New Brunswick, New Jersey: Rutgers UP, 2005.

LEYS, Ruth. 2000. Trauma: geneology, Chicago: University of Chicago Press.

https://periodicos.unifap.br/index.php/letras Macapá, v. 6, n. I, Io semestre, 2016. 
LOFFREDO, Ana Maria. Anotações sobre a leitura freudiana da angústia. Tempo psicanalítico. Rio de Janeiro, v. 44.i, p. 105-130, 2012.

LOURENCO, Lara Cristina D' Avila; VIANA, Milena de Barros;

PAULA, Danúbia Cristina de. A função da angústia na metapsicologia freudiana. Nat. hum. [online]. 2011, vol.13, n.1, p. 6583.

MENEZES, Adélia B. de. Vermelho, verde e amarelo: tudo era uma vez. Estudos avançados, v. 24, n. 69, 2010.

ROSA, J. G. Grande sertão: veredas. 19ª. Ed. Rio de Janeiro: Nova Fronteira, 2006.

- Primeiras estórias. 6.ed. Rio de Janeiro: José Olympio,1972.

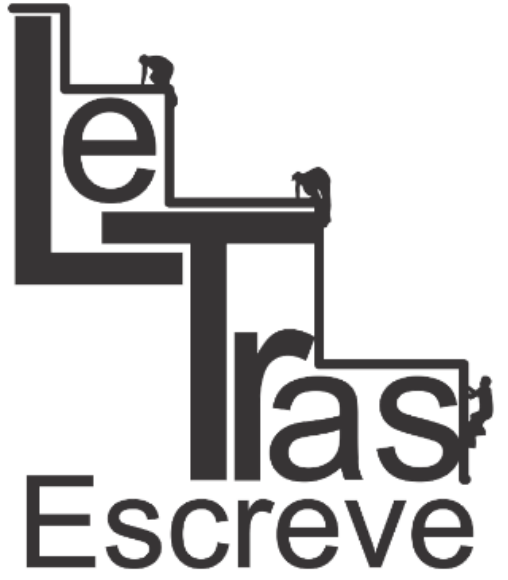

(ISSN 2238-8060)
. Ave palavra. Rio de Janeiro: Nova Fronteira, 1988.

. Fita Verde no Cabelo. Edição especial. Ilustr. Roger Mello. Rio de Janeiro: Nova Fronteira, 1992.

SELIGMANN-SILVA. M. A escritura da memória: mostrar palavras e narrar imagens. Remate de Males, 26(1) - jan./jun. 2006.

Recebido em 10/03/2016. Aprovado em 25/04/2016. 